\title{
TWO NEW SPECIES OF OXYETHIRA EATON (HYDROPTILIDAE: TRICHOPTERA: INSECTA) FOR TASMANIA
}

\author{
by Alice Wells
}

(with one text-figure)

\begin{abstract}
Wells, A., 2002 (31:xii): Two new species of Oxyethira Eaton (Hydroptilidae: Trichoptera: Insecta) for Tasmania. Papers and Proceedings of the Royal Society of Tasmania 136: 39-41. https://doi.org/10.26749/rstpp.136.39 ISSN 0080-4703.

Australian Biological Resources Study, Environment Australia, Canberra 2601, Australia.
\end{abstract}

Two new species collected recently from the World Heritage Area of Tasmania, are described in the microcaddisfly genus Oxyethira (Hydroptilidae: Trichoptera: Insecta). In addition, new records are given for Tricholeiochiton pennyae, biogeographically one of the more enigmatic Tasmanian hydroptilid species, and for Oxyethira tasmaniensis, both also known only from the Tasmanian World Heritage Area. Key Words: Tasmanian Trichoptera, new species, Hydroptilidae.

\section{INTRODUCTION}

Survey work in the Tasmanian World Heritage Area of southwestern Tasmania, using a combination of sweepnetting and pitfall-trapping, continues to yield new Trichoptera species, and to provide further data on others. Newly described here are two species of Oxyethira Eaton, $O$. driesseni and $O$. torquata, both of which conform in general features with members of subgenus Trichoglene.

Only two other hydroptilid species were taken with these new species. Both Oxyethira (Trichoglene) tasmaniensis Wells and Tricholeiochiton pennyae Wells were described from the World Heritage Area (Wells 1998) and, given the quite intensive collecting effort elsewhere in Tasmania, it is highly probable that all four species reported here are restricted to the World Heritage Area. Moreover, T. pennyae may exhibit behaviour atypical of hydroptilids. The bodies of both males and females of this species are unusually sturdy looking, and generally far more heavily sclerotised than is normal in the family. These features, coupled with the prevalence of this species in pitfall traps, suggest that $T$. pennyae may be far less able, or less likely, to fly than most other microcaddisflies. Given this possibility and the curious occurrence of this species so far south, with its closest congener in northeastern Queensland (Wells, 1998), this species warrants further investigation.

Depository institutions are abbreviated as follows: ANIC - Australian National Insect Collection, Canberra; NMV - Museum Victoria, Melbourne. Distribution refers to the provinces as used by Neboiss (1977).

\section{DESCRIPTIONS}

\section{Oxyethira (Trichoglene) driesseni Wells, 2002}

Fig. $1 \mathrm{~A}-\mathrm{C}$

\section{Material examined}

Holotype O Tasmania, Lake St Clair, Site RCE young, 17 Jan. 2000, ANIC. Paratypes: $30^{\star}$ o Tasmania, Lake St Clair, Site RCW old, 17 Jan. 2000, ANIC, NMV (10); q Lake St Clair, Site SCRW, 25 Nov. 2000, ANIC.
Length of forewing: $0^{*} 2.0-2.2 \mathrm{~mm}$. Resembling Oxyethira columba (Neboiss, 1977) and O. mienica Wells, 1981 in general form of male genitalia, but clearly distinguished from both by the greatly developed dorso-lateral processes tipped by an incurved hook above a tuft of setae and by tergite $\mathrm{X}$, which is apically acuminate.

Male genitalia (Fig. 1A-C) segment IX concave apicoventrally, produced posteriorly at dorso-lateral angles to form two processes, the most ventral of which is hooked apically and bears a tuft of setae subapically; dorsal plate (tergite IX) tapered sharply towards acuminate apex, a group of four papillae subapically on dorsal surface; inferior appendages reduced to small lobes, bearing a pair of setae apically; subgenital plate about as long as inferior appendages, membranous, with a long seta at each apicolateral angle; phallus extremely long, apically expanded and bearing a lateral spine.

\section{Etymology}

Named for Michael Driessen, whose collecting in the Tasmanian World Heritage Area has made a considerable contribution to knowledge of the Tasmanian fauna.

\section{Distribution}

Tasmania, C province. Known only from type locality. Tasmanian endemic.

\section{Oxyethira (Trichoglene) torquata Wells, sp. nov.}

Fig. 1D-F

\section{Material examined}

Holotype: $0^{\star}$ Tasmania, McPartlan Pass, Site 8A, 7 Mar. 2000, M. Driessen, ANIC. Paratypes: $\sigma^{\star}$ same data as for holotype, 8 Mar. 2000, NMV; E McPartlan Pass, Site 4B, 8 Mar. 2000, M. Driessen, ANIC; $0^{\star}$ McPartlan Pass, Site 10B, 8 Mar. 2000, M. Driessen, ANIC; O E McPartlan Pass, Site 1D, 14 Mar. 2000, M. Driessen, NMV; E McPartlan Pass, Site 9K, 15 Mar. 2000, M. Driessen, ANIC; \& McPartlan Pass, Site TRE O, 4 April 2000, M. Driessen, ANIC; O McPartlan Pass, Site TRW Y, 4 April 2000, M. Driessen, ANIC; $0^{\star}$ McPartlan Pass, Site 9A, 7 [month not 




Fig. $1-(A-C)$ Oxyethira (Trichoglene) driesseni sp. nov., male genitalia: $A$, ventral; $B$, lateral; $C$, dorsal views. ( $D-F)$ Oxyethira (Trichoglene) torquata sp. nov., male genitalia; $D$, ventral; $E$, lateral; $F$, dorsal views. Abbreviations: ae, aedeagus; $d p l$, dorsal plate; inf app, inferior appendages; lat IX, lateral lobes of abdominal segment IX; sp, lateral spine on dorsal plate.

recorded] 2001, M. Driessen, ANIC; O Airstrip Road Site 1B, 8 Mar. 2000, M. Driessen, ANIC.

Length of forewing: $\mathrm{O}^{*} 1.8-1.9 \mathrm{~mm}$. Distinguished from all other Tasmanian hydroptilids by the twisted, sclerotised lateral spines of the dorsal plate in the male genitalia.

Male genitalia (Fig. 1D-F) with segment IX wider than long ventrally and dorsally, but produced laterally to about length of genitalic parts; dorsal plate (tergite X) a membranous median plate flanked by a pair of darkly sclerotised, twisted spines; inferior appendages stoutly bilobed, the ventral lobe membranous, with subapical setae, the lateral lobe a pale spur; subgenital plate appears to be represented by a pair of elongate, distally swollen lobes, each with a seta apically; phallus slender, with a sharply hooked spine apically.

\section{Etymology}

Named for the twisted form of the lateral processes of dorsal plate.

\section{Distribution}

Tasmania, Central province. Known only from type locality. Tasmanian endemic.

\section{Oxyethira (Trichoglene) tasmaniensis Wells}

Oxyethira (Trichoglene) tasmaniensis Wells, 1998: 83.

Holotype $0^{\top}$ Tasmanian World Heritage Area, Southwest National Park, Melaleuca, 43⒉ $5^{\prime} 10^{\prime \prime S} 146^{\circ} 08^{\prime} 46^{\prime \prime E}$, (ANIC). 
Material examined

20`20 McPartlan Pass, Mar. 2000, Mar., April 2001.

Distribution

Tasmania, Central province. Tasmanian endemic.

\section{Tricholeiochiton pennyae Wells}

Tricholeiochiton pennyae Wells 1998: 82

Holotype $0^{\top}$ Tasmanian World Heritage Area, Southwest National Park, Melaleuca, 4331'00"S 146 09'41"E, (ANIC).

\section{Material examined}

80 80 King William Creek, Feb. 1999, Feb.-Mar. 2001; numerous ơ Lake St Clair, Mar. 1999, Jan., Mar., Nov. 2000; numerous ơ \& McPartlan Pass, Mar. 1999, Mar., April 2000; numerous ơ o Airstrip Road, 1999, Mar. 2000.
Distribution

Tasmania, Central province. Tasmanian endemic.

\section{REFERENCES}

Neboiss, A., 1977: A taxonomic and zoogeographic study of Tasmanian caddis-flies (Insecta: Trichoptera). Memoirs of the National Museum of Victoria 38: 1-208.

Wells, A., 1998: Two new species of Hydroptilidae (Trichoptera) from Tasmania's World Heritage Area. Australian Entomologist 25(3): 81-84.

(accepted 9 September 2002) 